\title{
Erratum for Euro Surveill. 2015;20(46)
}

Eurosurveillance editorial team ${ }^{1}$

1. European Centre for Disease Prevention and Control (ECDC), Stockholm, Sweden

Correspondence: Marco Cavaleri (Marco.Cavaleri@ema.europa.eu)

Citation style for this article:

Eurosurveillance editorial team. Erratum for Euro Surveill. 2015;20(46). Euro Surveill. 2015;20(47):pii=30069. D0I: http://dx.doi.org/10.2807/1560-7917. ES.2015.20.47.30069

Article published on 26 November 2015

In the article 'Sub-Saharan African migrants living with HIV acquired after migration, France, ANRS PARCOURS study, 2012 to 2013' (http://www.eurosurveillance.org/ ViewArticle.aspx?Articleld=21311) by Desgrées-du-Loû et al., published on 19 November 2015, the variables in the following sentence were corrected on 21 November 2015 .

The decline in $\mathrm{CD}_{4}^{+}$T-cell count (square root-transformed) over time was estimated using a linear mixed model with random intercept and slope, adjusted for individual $\mathrm{CD}_{4}{ }^{+} \mathrm{T}$-cell count at first $\mathrm{CD}_{4}{ }^{+} \mathrm{T}$-cell count measure $(x)$ duration from estimated date of HIV seroconversion to first $\mathrm{CD}_{4}{ }^{+}$T-cell count measure $\left(x_{2}\right)$ and age at HIV seroconversion $\left(x_{3}\right)$. 